\title{
СУБ'ЄКТ КОНТРАБАНДИ НАРКОТИЧНИХ ЗАСОБІВ, ПСИХОТРОПНИХ РЕЧОВИН, ЇХ АНАЛОГІВ ТА ПРЕКУРСІВ АБО ФАЛЬСИФІКОВАНИХ ЛІКАРСЬКИХ ЗАСОБІВ
}

На думку окремих учених, суб'єктом злочину в кримінальному праві $€$ фізична особа, яка вчинила передбачене кримінальним законом суспільно небезпечне діяння і яка характеризується визначеними в законі ознаками [1, с. 87]. Варто відзначити, що це визначення не безспірне, оскільки домінуючий у кримінальному праві підхід, що суб'єктом злочину може бути тільки фізична особа, останнім часом ставиться під сумнів. Крім цього, незрозуміло, якими ознаками повинен володіти суб'єкт, адже диспозиції багатьох кримінально-правових норм містять ознаки, властиві тільки окремим категоріям осіб, а не всім [2, с. 95].

Н.С. Лейкіна та Н.П. Грабовська розглядали як суб'єкта контрабанди наркотичних засобів фізичну, осудну особу, яка досягла певного віку [3, с. 56]. Правильно відзначивши необхідність наявності в суб'єкта таких ознак, як осудність i досягнення віку настання кримінальної відповідальності, вони не позначили ї зв'язок 3 можливістю вчинення злочинного діяння [3, с. 58].

Ще одне визначення дає С.В. Бородін: «суб'єктом злочину може бути не будь-яка особа, а тільки та, яка відповідно до кримінального закону характеризується певними ознаками» [4, с. 67]. До них належать встановлений законом вік, за досягнення якого можлива кримінальна відпо- відальність і осудність. Дійсно, не будь-яка особа може бути суб'єктом злочину, а тільки та, яка не тільки володіє певними ознаками, які визначені в законі, але й вчинила передбачене кримінальним законом суспільно небезпечне діяння.

Н.Ф. Кузнєцова і Ю.М. Ткачевський визнають суб'єктом злочину особу, яка вчинила умисне чи необережне суспільно небезпечне діяння, передбачене кримінальним законом, яка досягла встановленого віку, осудна, а іноді наділена спеціальними ознаками, які зазначені у відповідній нормі [5, с. 69].

Суб'єктом злочину, за визначенням П.С. Матишевського, вважається фізична особа, яка вчинила заборонене кримінальним законодавством діяння у віці, з якого може настати кримінальна відповідальність, а також яка усвідомлювала суспільну небезпечність такого діяння і керувала ним [6, с. 123]. Аналогічного погляду щодо поняття суб'єкта злочину дотримуються В.Я. Тацій, М.Й. Коржанський та інші автори $[7$, с. $67 ; 8$, с. 79$]$. Наведене визначення суб'єкта злочину не зовсім повне, оскільки воно фактично цитує положення ст. 18 KK України. Водночас ст. 20 КK України містить положення, згідно з яким «підлягає кримінальній відповідальності особа, визнана судом обмежено осудною, тобто така, яка під час вчинення злочину через наявний у неї психічний 
розлад не була здатна повною мірою усвідомлювати свої дії (бездіяльність) та (або) керувати ними». Таким чином, на думку С.В. Чорней, більш повним визначенням поняття «суб'єкт злочину» слід вважати фізичну осудну або визнану в установленому законом порядку обмежено осудною особу, яка вчинила заборонене кримінальним законодавством діяння у віці, з якого відповідно до КК Украіни може наставати кримінальна відповідальність [1, с. 126].

Виходячи 3 норм ст. 18 KK України, до ознак суб'єкта злочину законодавець відносить наявність статусу фізичної особи, досягнення передбаченого КK України віку кримінальної відповідальності та осудність. Таким чином, суб'єкт злочину характеризується такими ознаками:

1) суб'єктом злочину може бути тільки фізична особа; відповідно до ст. ст. 6-8 КК України передбачено, що підлягати кримінальній відповідальності можуть громадяни України, особи без громадянства та іноземці;

2) суб'єктом злочину може бути лише осудна особа.

Чинний КК України (2001р.), на відміну від КК УРСР (1960р.), вперше дає законодавче визначення осудності. Відповідно до ч. 1 ст. 19 КК України, осудною є особа, яка під час вчинення злочину могла усвідомлювати свої дії (бездіяльність) і керувати ними. Злочини, як і всі вчинки людини, визначаються і контролюються іiі свідомістю та волею. Лише психічно здорова особа може свідомо вибирати ті чи інші варіанти поведінки, розуміти характер i наслідки своїх діянь, проявляючи волю, керувати ними, тобто осудність - це нормальний стан психічно здорової людини. На практиці питання про встановлення осудності виникає лише за наявності сумнівів у психічній повноцінності особи, яка вчинила суспільно небезпечне діяння [8, с. 76].

Частиною 2 ст. 19 КK України передбачено, що неосудна особа не підлягає кримінальній відповідально- сті, яка під час вчинення суспільно небезпечного діяння, передбаченого КК України, перебувала в стані неосудності, тобто не могла усвідомлювати своїх дій (бездіяльності) або керувати ними внаслідок хронічного психічного захворювання, тимчасового розладу психічної діяльності, недоумства або іншого хворобливого стану психіки. На відміну від стану осудності, стан неосудності характеризується нездатністю особи усвідомлювати свої діяння або керувати ними, отже, виключає іï кримінальну відповідальність за вчинене діяння. Стан неосудності, як і стан осудності, з'ясовується лише в межах вчинення злочину та у зв'язку 3 ним [8, с. $77-78]$.

Відповідно до ч. 1 ст. 22 KK України, кримінальній відповідальності за вчинення злочину, передбаченого ст. 305 KK України, підлягає фізична осудна особа, яка до вчинення злочину досягла 16 років, є громадянином України, іноземцем або особою без громадянства (зокрема, особа, яка користується правом дипломатичного імунітету) [9, с. 73].

У теорії кримінального права особу, яка разом із загальними ознаками суб'єкта злочину (вік, осудність) володіє додатковими ознаками, виписаними у законі про кримінальному відповідальність, прийнято називати спеціальним суб'єктом. Відповідно до ч. 2 ст. $18 \mathrm{KK} \mathrm{України,} \mathrm{спеціальним}$ суб'єктом злочину є фізична осудна особа, яка вчинила злочин у віці, 3 якого може наставати кримінальна відповідальність, суб'єктом якого може бути лише певна особа, тобто спеціальним суб'єктом вважається особа, яка, крім зазначених трьох загальних ознак, має додаткові спеціальні ознаки, передбачені у статті Особливої частини КК України для суб'єкта конкретного злочину [9, с. 75].

Як зазначає M.I. Бажанов, спеціальним суб'єктом злочину є особа, яка наділена, крім зазначених загальних, спеціальними, додатковими ознаками, 
які їі характеризують та визначають кваліфікацію скоєного нею суспільно небезпечного діяння [10, с. 43].

На думку М.П. Карпушина, під спеціальним суб'єктом злочину, який вчиняє контрабанду з використанням свого службового становища, можуть розумітися такі особи, службове становище яких дає їм право провозити вантаж без митного огляду або здійснення митного контролю. Такими особами можуть бути працівники митних органів (наприклад, інспектори, контролери), службові особи прикордонних органів (здебільшого працівники контрольно-пропускних пунктів), посадові особи різноманітних делегацій, дип-представництв тощо [11, с. 166]. Ю.І. Сучков більше схильний до позиціï, яку займав М.П. Карпушин стосовно використання службовою особою свого службового становища як ознаки контрабанди, якщо ті чи інші особи незаконно перевозять через митний кордон товари, сподіваючись, що працівники митних органів їх не оглядатимуть у зв'язку зі службовим становищем, яке займають ці особи [12, с. 24-30].

За нагоди необхідно також звернути увагу на те, що однією з особливостей досліджуваного злочину $€$ та обставина, що його часто вчиняють особи 3 іноземним громадянством. Такими особами є студенти, туристи, працівники зарубіжних установ, які мають статутний капітал у спільних підприємствах на теритоpiї України тощо, які постійно мають можливість виїзду за межі нашої держави. У зв'язку з цим, як показує слідчо-оперативна практика, контрабандна діяльність цих осіб має продовжуваний характер, вчиняється здебільшого досить довгий час і складається з багатьох кримінальних епізодів [13, с. 79-80].

Окрім вищезазначеного, сьогодні існує гостра проблема притягнення до кримінальної відповідальності юридичних осіб, яка досі викликає активну полеміку серед науковців.
Пропонуємо розглянути цю проблему більш грунтовно.

Варто наголосити на тому, що з 27 держав ЄС у законодавстві більше половини 3 них передбачено можливість притягнення юридичних осіб до кримінальної відповідальності. Так, юридична особа підлягає кримінальній відповідальності у таких європейських державах, що входять до складу ЄС (наприклад, Королівство Бельгія, Сполучене Королівство Великобританіі і Північної Ірландії, Угорська Республіка, Королівство Данія, Республіка Ірландія, Республіка Мальта); що не входять до складу ЄC (Республіка Албанія, Республіка Ісландія, Республіка Македонія); у яких передбачена квазікримінальна, тобто адміністративно-кримінальна, відповідальність юридичних осіб (Австрійська Республіка, Італійська Республіка) [14, с. 111].

Таким чином, пропонуємо розглянути законодавство деяких зарубіжних країн про притягнення юридичних осіб до кримінальної відповідальності та виявити у них спільні, значущі риси.

Так, згідно з положеннями відомої в американському праві доктрини "Respondent superior", котра має цивілістичне походження, юридична особа може підлягати кримінальній відповідальності за незаконні діі своїх керівників, інших службових осіб, працівників, а також агентів, які діяли у межах службової компетенції і на користь організації [15, с. 56].

Слід зазначити, що юридичні особи у США можуть бути приватними або публічними [15, с. 78]. Окрім того, у Законі «Про іноземну корупційну практику» зазначено, що організаціі і пов'язані з нею фізичні особи «самостійно» і «незалежно» підлягають кримінальній відповідальності за корупційні діяння (глава 15 Зводу законів США, Секція 78dd-1 і далі). Кримінальне переслідування фізичних осіб, які $€$ виконавцями, підбурювачами, пособниками активного хабарництва чи відмивання грошей, не звільняє від кримінальної відповідальності організації. 
Достатньо поширена практика укладання юридичною особою «угоди про визнання вини» із зобов'язанням відшкодувати встановлену шкоду від незаконної діяльності в обмін на відмову обвинувальних органів переслідувати конкретних фізичних осіб [15, с. 95]. Саме таку практику можна було б запозичити для українського законодавства.

Відповідно до КК Французької Республіки $M$. Сапена та $M$. Рюдлоффа, парламент дав роз'яснення таким положенням:

1) виключити можливість притягнення до кримінальної відповідальності лише держави та місцевих органів самоуправління, якщо останні здійснюють функції, які не можуть бути делеговані іншим суб'єктам;

2) установити такі види покарань, які б унеможливлювали ліквідацію та здійснення судового нагляду публічно-правових юридичних осіб, політичних партій, рухів, профспілок тощо;

3) уточнити, що разом 3 відповідальністю юридичної особи можлива відповідальність фізичної особи виконавця чи співучасника цього злочинного діяння;

4) ввести для юридичних осіб п'ятикратний розмір штрафу, встановлений для фізичних осіб, а у випадку рецидиву - десятикратний [16, с. 134].

Згідно зі ст. 121-2 КК Французької Республіки, юридичні особи підлягають кримінальній відповідальності за діiі, вчинені від їх імені органами або приватними особами, які $€$ ï представниками, тому умовою кримінальної відповідальності юридичних осіб у Франції є вчинення злочинного діяння ii керівником чи представником [16, с. 137].

Французьке законодавство розрізняє юридичних осіб публічного й приватного права. До першого належать держава та уряд, місцева та регіональна влада, державні установи, професійні організації та групи публічного інтересу, а до другого асоціаціі, комерційні та некомерційні партнерства, групи економічних інтересів, профсоюзи, фонди, політичні партії та групи. У Французькій Республіці кримінальній відповідальності можуть також підлягати іноземні юридичні особи приватного права, коли юрисдикція французьких судів поширюється на вчинені діяння [16, с. 139].

Варто зазначити, що Французький кримінальний кодекс також установлює відповідальність юридичних осіб за досить широкий спектр злочинів, зокрема виготовлення, імпорт, експорт, перевезення, зберігання, передачу наркотиків [16, с. 149].

Обгрунтування необхідності притягнення до кримінальної відповідальності юридичних осіб можна знайти у законодавствах інших держав. Так, голландський учений Марк Хрунхаузен вважає найбільш важливими аргументами щодо встановлення кримінальної відповідальності юридичних осіб такі.

1) Гармонія в рамках правової системи. Юридичні особи давно визнаються суб’єктами права у цивільному й адміністративному праві. 3 огляду на значення юридичних осіб у житті суспільства бажано кримінальне право гармонізувати у цій площині 3 іншими галузями права.

2) Стаття $51 \mathrm{KK}$ Королівства Нідерландів призначена для того, щоб усунути прогалини у кримінально-правовій відповідальності. Часто неможливо встановити конкретну особу, яка вчинила злочин у підприємницькій сфері. Крім того, притягнення до відповідальності найманих працівників здебільшого практично не впливає на діяльність самого підприємства.

3) Як правило, особиста провина найманого робітника, який вчинив діяння, відносно мала. Покарання юридичної особи за таких умов здійснюється шляхом накладання санкцій, пропорційних шкоді, яка спричинена суспільству відповідним злочином [17, с. 34].

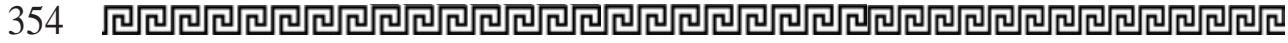


Такі аргументи, на наш погляд, є досить слушними і для українських реалій.

За англійським кримінальним законодавством, юридична особа $є$ самостійно діючою або бездіяльною особою, що юридично відрізняється від ii членів. Згідно із Законом «Про тлумачення правових термінів», вказівка на особу у формулюванні складів тих чи інших злочинів передбачає також юридичну особу, якщо інше прямо не встановлено законом. В англійській судовій практиці ніколи не виникало сумнівів у тому, що члени юридичної особи, наприклад їі службовці, можуть уникнути відповідальності. Вони підлягають кримінальній відповідальності за злочинні діяння, вчинені або санкціоновані ними [18, с. 21-22].

Загальні ж засади кримінальної відповідальності юридичних осіб передбачені Законом «Про тлумачення» 1978 р. Юридична особа в Англії може підлягати кримінальній відповідальності за корупційні діяння, відмивання доходів i фінансування тероризму (торгівля впливом, на відміну від США, в Англії не криміналізована) [18, с. 65].

У законодавствах держав континентальної Європи також наявні норми, які вказують на певне коло фізичних осіб, злочинні діï яких визнаються діями юридичної особи. Так, ст. 2 (1) KК Угорщини зазначає, що юридична особа підлягає кримінальній відповідальності, якщо злочин був вчинений одним з іiі учасників або менеджерів чи представників, наділених правами керувати цією юридичною особою або представляти ii інтереси, чи контролюючим членом ii правління i/або його представниками (ст. 2 (1) а); одним з іï учасників чи працівників, коли з боку керівника, наділеного відповідними повноваженнями, спостерігається недостатній контроль (ст. 2 (1) b); третьою особою за умови, що представники компанії, які надали їй права управління юридичною особою, знали про вчинення протиправних дій (ст. 2 (2) Закону) [19, с. 98].

Відповідно до ст. 3 Закону Республіки Польща «Про відповідальність колективних суб'єктів за дії, заборонені під загрозою покарання» від 28 жовтня 2002 р., підставою кримінальної відповідальності юридичної особи є неправомірна поведінка фізичної особи, яка діє від імені або на користь колективного суб'єкта у межах повноважень або обов'язків щодо його представництва, прийняття від його імені рішень чи виконання внутрішнього контролю або в разі перевищення делегованих повноважень чи неналежного виконання покладених на фізичну особу обов'язків; діє з перевищенням повноважень чи неналежно виконує свої обов'язки; діє в інтересах або від імені колективного суб'єкта за згодою або з відома особи, зазначеної у п. 1 цієї статті; є підприємцем [20, с. 34-35].

У Словеніі, відповідно до Закону «Про відповідальність юридичних осіб за злочинні дії 1999 р., юридичні особи підлягають кримінальній відповідальності, якщо проступок був вчинений фізичною особою від імені юридичної особи і на їі користь. Відповідальність організацій настає за винесення керівним органом незаконного рішення чи наказу або його підтримку; спонукання чи сприяння злочинцю з боку органів управління; неналежний контроль керівництва за законністю дій службовців компанії.

У ст. 21 Закону Словенії «Про відповідальність юридичних осіб за злочинні діï, крім штрафу, конфіскації майна та ліквідації юридичної особи, передбачено два таких додаткових обмеження для організацій: заборона діяльності на основі ліцензій, дозволів чи концесій, наданих державними органами; заборона у придбанні ліцензій, використання концесій, що можна врахувати у вітчизняному законодавстві стосовно підприємств, які отримують ліцензії на заняття господарською діяльністю, а саме виробництво лікарських засобів [20, с. 45]. 
Досвід зарубіжних держав щодо покарання юридичних осіб за вчинення злочинів видається досить корисним, а цілу низку покарань можна було б застосовувати в національному кримінальному праві, адже певні кроки у цьому напрямі вже зроблені. Наприклад, відомий Проєкт КK України 1993 р. (далі - Проєкт $\mathrm{KK}$ ), розроблений авторським колективом під керівництвом професора B.M. Смітієнка, передбачав можливість притягнення юридичних осіб до кримінальної відповідальності. У Проєкті було зазначено, що в сучасних умовах істотно зростають можливості вчинення злочинів юридичними особами у сфері економіки, фінансування та деяких інших сферах. Однак усі ці злочини для чинного кримінального законодавства $є$ недосяжними, оскільки всі вони вчиняються від імені колективного органу юридичної особи. На думку авторів Проєкту, відсутність відповідальності юридичних осіб призводить до безкарності посадових осіб усіх рангів, які, приймаючи колективне злочинне рішення, реально уникають відповідальності.

У ч. 1 ст. 27 Проєкту КК (Відповідальність юридичних осіб) караним діянням, вчиненим юридичною особою, визнається заборонена цим Кодексом дія або бездіяльність, виконана або санкціонована ії керівником чи колективним органом управління, що діяв із порушенням своїх повноважень, від імені юридичної особи. У Проєкті зазначено, що юридичні особи можуть підлягати кримінальній відповідальності за злочини проти миру й безпеки людства, а також здоров'я населення, що є дотичним до нашої теми, проти держави, у сфері природокористування і народного господарства лише у випадках, спеціально передбачених нормами Особливої частини цього Кодексу (ч. 2 зазначеної статті), тобто коло таких злочинів $є$ досить широким [20, с. 11-12].

Водночас варто згадати про прийнятий Закон України «Про відповідальність юридичних осіб за вчинення корупційних правопорушень» від 11 червня 2009 р. (втратив чинність 5 січня 2011 р.), який у ст. 3 передбачав можливість застосування до юридичних осіб таких видів покарань, як штраф, заборона займатись певним видом діяльності, конфіскація майна та ліквідація юридичної особи [21, с. 33].

B.K. Грищук та О.Ф. Пасєка висловлюють думку у своїй монографіï про необхідність запровадження до законодавства України кримінальної відповідальності юридичних осіб, зокрема, за злочин, передбачений ст. 305 КК України [22, с. 215-220].

Обгрунтовуючи доцільність кримінальної відповідальності юридичних осіб у розрізі теми нашого дослідження, зазначаємо, що чинне законодавство України передбачає низку нормативно-правових актів, які регулюють діяльність юридичних осіб, пов'язану з виробництвом лікарських засобів, отриманням ліцензії на заняття такою діяльністю, культивуванням рослин, які містять наркотичні речовини, виробництвом лікарських засобів, які містять наркотичні засоби або прекурсори, а також експорт таких лікарських засобів, а саме ЗУ «Про ліцензування господарської діяльності» в редакції від 13 серпня 2020 р., Закон «Про наркотичні засоби, психотропні речовини та прекурсори» в редакції від 5 липня 2020 р., Закон «Про лікарські засоби» в редакції від 5 липня 2020 р., Закон «Про заходи протидії незаконному обігу наркотичних засобів» в редакціі від 3 липня 2020 р., Постанову Кабінету Міністрів «Про затвердження Порядку видачі дозволів на право ввезення на територію України, вивезення з території України або транзиту через територію України наркотичних засобів, психотропних речовин і прекурсорів» від 3 лютого 1997 р. № 146, Постанову Кабінету Міністрів «Про деякі питання ліцензування господарської діяльності з культивування рослин, включених до таблиці I переліку наркотичних засобів, пси- 
хотропних речовин і прекурсорів, затвердженого Кабінетом Міністрів України, розроблення, виробництва, виготовлення, зберігання, перевезення, придбання, реалізації (відпуску), ввезення на територію України, вивезення з території України, використання, знищення наркотичних засобів, психотропних речовин і прекурсорів, включених до зазначеного переліку» від 6 квітня 2016 р. № 282, Постанову Кабінету Міністрів «Про затвердження гранично допустимої кількості наркотичних засобів, психотропних речовин і прекурсорів, що містяться в препаратах» від 10 червня 2007 р. № 1203. Станом на початок 2020 р. до Державної служби Украіни з лікарських засобів та контролю за наркотиками було подано близько 70 заяв на ліцензування господарської діяльності з виробництва лікарських засобів, імпорту лікарських засобів (крім активних фармацевтичних інгредієнтів), оптової та роздрібної торгівлі лікарськими засобами, обігу наркотичних засобів, психотропних речовин і прекурсорів, що вказує на динаміку зростання кількості юридичних осіб з виготовлення лікарських засобів порівняно 3 попередніми роками [23].

Так, враховуючи позитивний зарубіжний досвід, спроби у вигляді Закону України «Про відповідальність юридичних осіб за вчинення корупційних правопорушень», Проєкту КK України 1993 р., розробленого авторським колективом під керівництвом професора В.М. Смітієнка, глибоку аргументацію вітчизняних науковців щодо необхідності запровадження у чинному законодавстві кримінальної відповідальності юридичних осіб, в нашому випадку - тих, що пов'язані з виробництвом лікарських засобів, отриманням ліцензіі на заняття такою діяльністю, культивуванням рослин, які містять наркотичні речовини, виробництвом лікарських засобів, які містять наркотичні засоби або прекурсори, та їх експорту, вважаємо за доцільне, окрім загального та спе-

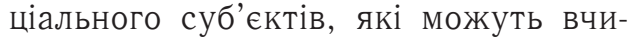
няти злочин, передбачений ст. 305 KK України, розширити вищезазначений перелік поняттям «юридична особа» та доповнити ст. 3 ППВСУ «Про судову практику в справах про злочини у сфері обігу наркотичних засобів, психотропних речовин, ї аналогів або прекурсорів» від 26 квітня 2002 р. № 4 тим самим поняттям з урахуванням таких ознак:

1) підставою кримінальної відповідальності юридичних осіб є вчинення злочину посадовою особою, агентом або представником такої організації, тобто обов'язковою умовою $€$ наявність людського субстрату - фізичної особи, яка має право діяти від імені особи юридичної;

2) відповідальність юридичних осіб виступає як додаткове покарання і не звільняє від відповідальності винних фізичних осіб;

3) юридична особа підлягає кримінальній відповідальності за такі види протиправної діяльності, як корупція, легалізація доходів, отриманих злочинним шляхом (від продажу контрабандних наркотичних засобів, психотропних речовин, їх аналогів та прекурсорів або фальсифікованих лікарських засобів), а також фіктивна підприємницька діяльність;

4) кримінальній відповідальності підлягають юридичні особи приватного права;

5) до юридичних осіб застосовуються такі види покарань, як конфіскація майна, ліквідація юридичної особи, постійна чи тимчасова заборона здійснення діяльності, скасування ліцензії на заняття певним видом діяльності.

Суб'єкт злочину разом з об'єктом, об'єктивною та суб'єктивною сторонами є обов'язковим $i$ самостійним елементом будь-якого складу злочину, зокрема, передбаченого ст. 305 КК України. Відсутність суб’екта виключає наявність 
складу злочину загалом $і$ зумовлюе відсутність підстав для притягнення особи до кримінальної відповідальності. Ознаки, що характеризують суб'єкта, нерозривно пов'язані з усіма іншими елементами складу злочину. Саме своїм суспільно небезпечним діянням суб'єкт завдає шкоди об'єкту посягання, діючи при изьому винно.

Незважаючи на те, шо положення стосовно суб'єкта злочину є досить усталеними у кримінальному праві, все одно на теоретичному й нормативному рівнях виникають дискусійні питання, пов'язані з визначенням поняття суб'єкта злочину, передбаченого ст. 305 КК України, спеціального суб'єкта злочину, ї ознак та змістовної характеристики, а також доцільності визначення юоидичних осіб суб'єктом злочину, що є актуальною проблемою та метою нашого дослідження.

У статті проаналізовано теоретичні підходи вітчизняних науковцуів до визначення поняття суб’єкта злочину, його ознак, встановлено відмінності між загальним та спеціальним суб'єктами злочину, передбаченого ст. 305 КК України. Встановлено та охарактеризовано основні риси відповідальності юридичних осіб зарубіжних держав, виділено значущі ознаки, які можна запозичити для українського законодавства. Водночас наведено позитивні приклади намагань впровадження до вітчизняного законодавства відповідальності юридичних осіб, які, на жаль, поки що не набули реалізації у практичній діяльності.

В результаті аналізу вищезазначених думок, положень, позитивного зарубінного досвіду, враховуючи реаліі сьогодення, пропонуємо удосконалення чинного законодавства иляхом впровадження до ст. 305 КК України відповідальності, окрім загального та спеціального суб’єктів, відповідальності юридичних осіб, які виступатимуть як додаткове пока- рання, не звільняючи від відповідальності винних фізичних осіб.

Ключові слова: загальний суб'єкт, спеціальний суб'єкт, ознаки суб'єкта, юридичні особи.

Koziaruk O. Subject of the smuggling of drugs, psychotropic substances, their analogues and percussions or counterfeit medicines

The subject of the crime, along with the object, the objective party and the mental element, is a mandatory and independent element of any corpus delict, in particular, prescribed in the article 305 of the Criminal Code of Ukraine. The absence of a subject excludes the presence of corpus delict in general and predetermines the absence of grounds for bringing a person to justice. The signs that characterize the subject are linked with all other elements of the crime. It is by his socially dangerous act that the subject inflicts on the object of the encroachment, while acting guiltily.

Despite the fact that the position connected to the subject of a crime is quite well-established in criminal law, however, on the theoretical and at the normative levels we can notice some controversial issues related to the definition of the concept of the subject of the crime prescribed in the article 305 of the Criminal Code of Ukraine, a special subject of a crime, their signs and meaningful characteristics, as well as the expediency of defining legal entities as a subject of a crime, which today is a very urgent problem and the goal of our research.

There are some analysis of the theoretical approaches of national researchers regarding the definition of the concept of the subject of the crime, its signs, establishes the differences between the common and special subjects of the crime prescribed in the article 305 of the Criminal Code of Ukraine in the article. The main features of the liability of the legal entities of foreign states have 
been established and characterized, the significant features have been identified that can be also borrowed for Ukrainian legislation. At the same time, there are given positive examples of attempts to introduce liability of the legal entities into domestic legislation, which, unfortunately, have not yet been implemented in practice.

As a result of the analysis of the all above thoughts, provisions, positive foreign experience, taking into account the realities, it is proposed to improve the current legislation by introducing to the article 305 of the Criminal Code of Ukraine, in addition to common and special subjects, also liability of the legal entities, which will act as an additional punishment, without exemption from punishment the physical persons who are guilty.

Key words: common subject, special subject, characteristics of the subject, legal entities.

\section{Література}

1. Чорней С.В. Поняття суб'єкта злочину. Науковий вісник Чернівещького університету. Серія «Право». 2012. Bun. 618. № 13. C. 125-128.

2. Уголовное право России: Общая часть : учебник / под ред. А.И. Рарога. Москва : Триада ЛТД, 1997. 560 с.

3. Курс советского уголовного права: Общая часть. Москва: Наука, 1968. 649 c.

4. Багрий-Шахматов Л.В. Социально-правовые проблемь уголовной ответственности и форм ее реализации. Часть вторая. Одесса, 2000. 412 c.

5. Кузнецова Н.Ф. Перспективы совершенствования УК РФ. Государство и право на рубеже веков. Криминология, уголовное право, судебное право : материаль Всероссийской конференции (2-3 февраля 2001 г., Москва). Москва, 2001. 345 с.

6. Матишевський П.С. Кримінальне право України. Загальна частина. Київ, 2001. 352 c.

7. Тацій В.Я. Кримінальне право Украіни. Загальна частина. Київ, 2002. 416 с.

8. Чернишова Н.В. Кримінальне право України (Загальна частина) : навчальний посібник. Київ, 2003. 288 с.

9. Науково-практичний коментар Кримінального кодексу України / за ред. М.I. Мельника, М.I. Хавронюка. Київ, 2002. $1104 \mathrm{c}$.
10. Бажанов М.И. Уголовное право Украинь. Общая часть. Днепропетровск, 1992. 167 c.

11. Дьяков С.В. Ответственность за государственные преступления / под общ. ред. Я.И. Баркова. Москва, 1988. 224 с.

12. Сучков Ю.И. Контрабанда и ответственность. Калининград, 1975. 40 с.

13. Луценко Ю.В., Полторацьький О.Б., Тарасюк А.В. Суб'єкт контрабанди наркотичних засобів у теорії кримінального права України. Науковий вісник Дніпропетровського державного університету внуmpiurix справ. 2018. № 1. С. 73-80.

14. Крылова Н.Е. Уголовная ответственность юридических лии во Франции: предпосылки возникновения и основные чертьь. Вестник Московского универсиmema. 1998. № 3. C. 69.

15. Никифоров Б.С. Современное американское уголовное право. Москва, 1990. 540 с.

16. Уголовнаи кодекс Франции / науч. ред. Л.В. Головко, Н.Е. Крыловой. Санкт-Петербург : Юридический центр Пресс, 2002. 412 c

17. Хрунхаюзен М. Некоторые основы и главные приниипы Нидерландского уголовного кодекса / науч. ред. Б.В. Волженкина. Санкт-Петербург, 2001. 290 с.

18. Михайлов О.О. Юридична особа як суб'єкт злочину: іноземний досвід та перспективи його застосування в Україні: дис. ... канд. юрид. наук : спеи. 12.00.08. Київ, 2008. 157 c.

19. Бирюков П.Н. Уголовная ответственность юридических лии за преступления в сфере экономики (опьт иностранных государств). Москва, 2008. 136 с.

20. Смітієнко B.M. Відповідальність юридичних осіб - нагальна потреба кримінально-правового регулювання. Голос України. 1996. № 43. С. 9.

21. Грищук В.К. До питання про кримінальну відповідальність юридичних осіб. Актуальні проблеми кримінального $і$ кримінально-процесуального законодавства $i$ практики його застосування: збірник тез доповідей учасників Регіонального круглого столу (Хмельницький, 21-22 лютого 2003 р.). Хмельницький, 2003. С. 45-49.

22. Грищук В.К. Кримінальна відповідальність юридичних осіб: кримінально-правове дослідження : автореф. дис. ... канд. юрид. наук : спец. 12.00.08. Київ, 2013. 217 c.

23. Офіційний сайт Державної служби України з лікарських засобів та контролю за наркотиками. URL: https: / / wwr.dls. gоv.иа (дата звернення: 15.09.2020). 